\title{
Article \\ Effect of Precipitated Precursor on the Catalytic Performance of Mesoporous Carbon Supported CuO-ZnO Catalysts
}

\author{
Yandong Li ${ }^{1,2, *}$, Guangfen Liang ${ }^{2}$, Chengrui Wang ${ }^{2}$, Yanhong Fang ${ }^{2}$ and Huamei Duan ${ }^{2, * \text { (D) }}$ \\ 1 Chongqing Key Laboratory of Extraordinary Bond Engineering and Advanced Materials Technology, \\ Yangtze Normal University, Chongqing 408100, China \\ 2 Laboratory of Metallurgy and Materials, College of Materials Science and Engineering, Chongqing University, \\ Chongqing 400044, China; liangguangfen@cqu.edu.cn (G.L.); wangchengrui@cqu.edu.cn (C.W.); \\ fangyanhong@cqu.edu.cn (Y.F.) \\ * Correspondence: liyd@yznu.edu.cn (Y.L.); duanhuamei@cqu.edu.cn (H.D.)
}

\section{check for}

updates

Citation: Li, Y.; Liang, G.; Wang, C.; Fang, Y.; Duan, H. Effect of

Precipitated Precursor on the

Catalytic Performance of Mesoporous

Carbon Supported CuO-ZnO

Catalysts. Crystals 2021, 11, 582 .

https: / / doi.org/10.3390/

cryst11060582

Academic Editors: Fatih Gulec,

Yongliang (Harry) Yan, Peter Clough and Vladislav V. Kharton

Received: 10 April 2021

Accepted: 11 May 2021

Published: 22 May 2021

Publisher's Note: MDPI stays neutral with regard to jurisdictional claims in published maps and institutional affiliations.

Copyright: (C) 2021 by the authors. Licensee MDPI, Basel, Switzerland This article is an open access article distributed under the terms and conditions of the Creative Commons Attribution (CC BY) license (https:// creativecommons.org/licenses/by/ $4.0 /)$

\begin{abstract}
As part of concepts for chemical energy storage of excess chemical energy produced from renewable sources, we investigated the performance of $\mathrm{CuO} / \mathrm{ZnO}$ catalysts supported on mesoporous carbon to convert $\mathrm{CO}_{2}$ hydrogenation to methanol. In this work, mesoporous carbon was used as the catalyst support for $\mathrm{CuO}-\mathrm{ZnO}$ catalysts. Four catalysts with different precipitated precursors were synthesized and analyzed by $\mathrm{N}_{2}$-physisorption, $\mathrm{X}$-ray diffraction (XRD), thermogravimetric analysis (TG-DTG), scanning electron microscopy (SEM) and transmission electron microscopy (TEM). The results show that catalyst CZ-in situ had the highest turnover frequency (TOF) $\left(2.8 \times 10^{-3} \mathrm{~s}^{-1}\right)$ and methanol production rate $\left(0.8 \mathrm{mmol} \mathrm{g}^{-1} \cdot \mathrm{h}^{-1}\right)$. The catalysts for co-precipitation of copper and zinc on carbon precursors are more active. $\mathrm{Cu} / \mathrm{ZnO}$ domains that are accessible to the reactant gas are another reason for the catalysts being active. The $\mathrm{Cu}-\mathrm{ZnO}$ interface is crucial to methanol catalyst activity.
\end{abstract}

Keywords: mesoporous carbon; $\mathrm{CO}_{2}$ hydrogenation to methanol; precipitated precursor; catalytic performance

\section{Introduction}

Rapid economic development cannot be separated from firm dependence on fossil fuel. However, the cost is rising $\mathrm{CO}_{2}$ emissions. Because of the consumption of fossil fuel, the original balance between carbon and oxygen is broken, which leads to a series of serious problems, such as global warming, sea level rise and Arctic glacier melting [1-3]. According to the statistics of the International Energy Agency (IEA), global energy-related carbon dioxide $\left(\mathrm{CO}_{2}\right)$ emissions plateaued in 2019 at $33.3 \mathrm{Gt}$. Compared with 2010 (30.4 Gt), they increased by $9.54 \%$ [4]. Therefore, how to reduce $\mathrm{CO}_{2}$ emissions and convert carbon dioxide into other chemical raw materials have aroused the interest of researchers $[5,6]$. Among these techniques, $\mathrm{CO}_{2}$ hydrogenation to methanol is one of the most effective and economical ways to reduce $\mathrm{CO}_{2}$ emission $[7,8]$. In this way, the closed-loop utilization from fossil fuel to $\mathrm{CO}_{2}$ and then from $\mathrm{CO}_{2}$ to fuel can be realized.

$\mathrm{CO}_{2}$ has stable chemical properties and the dissociation energy of the $\mathrm{C}=\mathrm{O}$ bond reaches up to $750 \mathrm{~kJ} \cdot \mathrm{mol}^{-1}$ [9]. Therefore, catalysts have been becoming the core of methanol industrial synthesis processes. At present, $\mathrm{Cu} / \mathrm{ZnO}$-based $[10,11]$ catalysts have been widely applied and prepared by the co-precipitation method $[12,13]$. Obviously, the catalytic performance is significantly influenced by different preparation conditions and features of the catalyst materials. Two key factors are the phase and composition of the catalyst precursor. The effect of the precursor on methanol catalyst activity has been reported in many studies [14-17]. Himelfarb et al. [18] studied the co-precipitation method with a $\mathrm{Cu} / \mathrm{Zn}$ ratio of $3: 7$, resulting in only a $\left(\mathrm{Cu}_{0.3} \mathrm{Zn}_{0.7}\right)_{5}\left(\mathrm{CO}_{3}\right)_{2}(\mathrm{OH})_{6}$ phase in the precursor. Pollard $[19,20]$ studied the phase transition process of the precipitates in the 
mother liquor. Firstly, the reaction generated amorphous basic cupric carbonate georgeite $\left(\mathrm{Cu}_{2} \mathrm{CO}_{3}(\mathrm{OH})_{2}\right)$. Then, it transformed into crystalline malachite $\left(\mathrm{Cu}_{2} \mathrm{CO}_{3}(\mathrm{OH})_{2}\right)$ gradually during the aging process. Finally, zincian malachite $(\mathrm{Cu}, \mathrm{Zn})_{2} \mathrm{CO}_{3}(\mathrm{OH})_{2}$ could be formed and it was the only precursor for the formation of highly active catalysts. Li [19] claimed that georgeite was also a possible candidate for the catalyst precursor. While azurite as a precursor for preparing a methanol synthesis catalyst is active, the performance is inferior to zincian malachite. There is controversy regarding catalyst precursors. In this paper, we report the different $\mathrm{Cu}$ or $\mathrm{Zn}$ precursors for the catalysts. The role of catalyst precursors may be more complex than that had been realized before.

High surface-area supports generally contain mesopores and micropores that are important to the activity and selectivity. Mesoporosity is preferred over microporosity for most catalytic applications because a mesoporous network can make reactants and products more convenient for diffusion [21]. Van Den Berg and coworkers [22,23] were the first researchers to report the function of mesoporous silica as the support for methanol synthesis catalysts and it showed many advantages. Mesoporous carbon has a similar structure to mesoporous silica. However, different surface chemistry has not been investigated in methanol synthesis. In 2014, our findings [24] suggested that these FDU-15 carbon-supported $\mathrm{Cu}$ and $\mathrm{ZnO}$ catalysts showed advantages for $\mathrm{CO}_{2}$ conversion and may potentially be better catalysts for methanol production. In the same year, we proposed a facile method for synthesis of a mesoporous carbon-supported methanol catalyst containing well dispersed $\mathrm{Cu} / \mathrm{ZnO}$. The results proved that this was an effective way to control the dispersion of metal oxide particles [25]. In 2017, we investigated the catalytic performance of a $\mathrm{Cu} / \mathrm{ZnO}$ catalyst supported on mesoporous carbon FDU-15, which was closely related to the factors of calcination temperature, ramping rate and metal loading [26]. Those results confirmed that mesoporous carbon was a very promising catalyst support for methanol conversion.

In order to address the effect of the $\mathrm{Cu} / \mathrm{Zn}$ precursors on the catalytic performance, we investigated four catalysts with different catalyst precursors supported by mesoporous carbon FDU-15 (MC). The precursors and the catalysts were characterized by the means of $\mathrm{N}_{2}$-physisorption, XRD, TG-DTG, SEM and TEM. The catalytic performances were tested in a fixed-bed reactor.

\section{Experimental}

\subsection{Materials}

$\mathrm{Cu}\left(\mathrm{NO}_{3}\right)_{2} \cdot 2.5 \mathrm{H}_{2} \mathrm{O} ; \mathrm{Zn}\left(\mathrm{NO}_{3}\right)_{2} \cdot 6 \mathrm{H}_{2} \mathrm{O}$, Pluronic F127, formaldehyde solution (37 wt. \%), phenol, sodium carbonate, sodium hydroxide and anhydrous ethanol were analytical regents and were purchased from Sigma-Aldrich Chemicals Corp. New South Wales, Australia. All the reagents were purchased and used without further purification.

\subsection{Experimental Method}

\subsubsection{Preparation of Stage A Phenolic Resin Pre-Polymers}

Stage A phenolic resin is a kind of soluble phenolic resin with a low molecular weight, which was prepared from phenol and formaldehyde under the condition of alkali catalysis [27]. Firstly, $9.15 \mathrm{~g}$ phenol was dissolved in deionized water at $40-42{ }^{\circ} \mathrm{C}$. Then, the $20 \mathrm{wt} . \% \mathrm{NaOH}$ solution $(1.95 \mathrm{~g}$ ) was added and stirred for $10 \mathrm{~min}$. Next, $37 \mathrm{wt} . \%$ formaldehyde solution ( $15.75 \mathrm{~g}$ ) was added, and then the temperature was raised to $70-75^{\circ} \mathrm{C}$ for $1 \mathrm{~h}$. Finally, the temperature was cooled to room temperature, and the $\mathrm{pH}$ adjusted to $\mathrm{pH}=7-8$ with $0.6 \mathrm{~mol} / \mathrm{L} \mathrm{HCl}$ solution. The mixture was dehydrated to a viscous liquid $\left(1-2 \mathrm{~h}\right.$ ) under vacuum at less than $50^{\circ} \mathrm{C}$. The viscous liquid was dissolved in ethanol to form a uniform solution with a concentration of $20 \mathrm{wt} . \%$ for standby.

\subsubsection{Synthesis of Mesoporous Carbon (MC)}

MC was prepared by a solvent volatilization-induced self-assembly process in ethanol solution by using phenolic resin as the polymer precursor and F127 as the template. In this 
process, the ratio of phenolic resin: F127: ethanol was 1:1:20 (mass ratio). Generally, we dissolved F127 (4.0 g) in ethanol (20 g) and stirred the solution until clarification. Then, we added $20 \mathrm{~g} 20 \mathrm{wt} . \%$ of the stage A phenolic resin ethanol solution into the solution. After that, we added the required ethanol solution to meet the set proportion of the solution, and stirred for $30 \mathrm{~min}$ to obtain a uniform solution. The solution was transferred to the dish, kept at room temperature for $5 \mathrm{~h}$, and then the dish was kept in a $100{ }^{\circ} \mathrm{C}$ oven for $24 \mathrm{~h}$ to obtain transparent film materials. The material was scraped off the dish and ground to powder, and as-made FDU-15 was recorded. MC was obtained by roasting as-made FDU-15 in a tube furnace under $\mathrm{N}_{2}$ protection. The roasting conditions were as follows: $\mathrm{N}_{2}$ flow rate was $50 \mathrm{~cm}^{3} \cdot \mathrm{min}^{-1}$, heating rate was $2{ }^{\circ} \mathrm{C} \cdot \mathrm{min}^{-1}$, constant temperature was kept at $350^{\circ} \mathrm{C}$ for $2 \mathrm{~h}$, then temperature was increased to $700{ }^{\circ} \mathrm{C}$ for $2 \mathrm{~h}$ at the same heating rate, and then reduced to room temperature in an $\mathrm{N}_{2}$ atmosphere.

\subsubsection{Supported Catalyst Prepared by Precipitation Method}

The catalysts were prepared by the precipitation method. A certain amount of nitrate was dissolved in a flask with $50 \mathrm{~mL}$ deionized water. The flask was placed in a magnetic stirring oil bath with a stirring speed of $300 \mathrm{r} \cdot \mathrm{min}^{-1}$ at a temperature between 68 and $72{ }^{\circ} \mathrm{C}$. We added $8 \mathrm{wt} . \%$ sodium carbonate solution to adjust to $\mathrm{pH}=7-8$ under continuous stirring. We maintained the $\mathrm{pH}$ and aging for $3 \mathrm{~h}$. This was followed by filtration and the separated solids were rinsed several times with deionized water. The solid was dried at $100{ }^{\circ} \mathrm{C}$ for $10 \mathrm{~h}$. The precipitated precursor of $\mathrm{Cu}$ was denoted as $\mathrm{Cu}$ precipitate. The precipitated precursor of zinc was denoted as $\mathrm{Zn}$ precipitate, and the precursor of $\mathrm{Cu}$ and $\mathrm{Zn}$ was denoted as $\mathrm{Cu} \mathrm{Zn}$ precipitate. The $\mathrm{Cu} \mathrm{Zn}$ precipitate was added to the homogeneous solution stage A phenolic resin and ethanol of F127. The rest conditions were the same with $\mathrm{MC}$ and the carbonization temperature was $700{ }^{\circ} \mathrm{C}$. The catalyst was denoted as CZ-postprecipitation (CZ-post). Cu precipitate was added to the stage A phenolic resin, F127 and zinc nitrate in ethanol solution. The rest of the conditions were the same with CZ-post. This catalyst was denoted as C-post-precipitation (C-post). Zn precipitate was added to the homogeneous stage A phenolic resin, F127 and zinc nitrate in ethanol solution and the rest of the conditions were the same as for preparation of C-post. This catalyst was denoted as Z-post. A certain amount of MC was placed in a flask containing $50 \mathrm{~mL}$ deionized water, to which was added the required copper nitrate and zinc nitrate. The $8 \mathrm{wt} . \%$ sodium carbonate solution was added to adjust to $\mathrm{pH}=7-8$. The remaining steps were the same as for the preparation method of the precipitated precursor. The product was roasted in an $\mathrm{N}_{2}$ atmosphere at $300{ }^{\circ} \mathrm{C}$ for $3 \mathrm{~h}$, and the catalyst was denoted as $\mathrm{CZ}$-in situ.

\subsection{Catalyst Characterization and Performance Testing}

Nitrogen $\left(\mathrm{N}_{2}\right)$ physisorption analysis was measured on a Micromeritics TriStar sorption analyzer (Norcross, GA, USA) and a Micromeritics ASAP 2020 gas adsorption analyzer (Norcross, GA, USA) at $-196^{\circ} \mathrm{C}$. Powder X-ray diffraction (XRD) analysis was performed on a Philips PW1130 powder diffractometer (Eindhoven, Dutch) with $\mathrm{Cu} \mathrm{K} \alpha$ radiation $(\lambda=1.5405 \AA)$ at $40 \mathrm{kV}$ and $25 \mathrm{~mA}$. Thermal decomposition was performed on an apparatus that enabled the simultaneous recording of TG and DTG signals (TGA/SDTA 851) in the temperature range $30-700{ }^{\circ} \mathrm{C}$ with a ramping rate of $2{ }^{\circ} \mathrm{C} / \mathrm{min}$ under a nitrogen atmosphere. The metal loading of the four catalysts was obtained by burning off the carbon support in an $\mathrm{O}_{2}$ atmosphere with a ramping rate of $2{ }^{\circ} \mathrm{C} / \mathrm{min}$. The morphology of the catalysts was investigated on a JEOL 7001F FEG scanning electron microscope (SEM) (Tokyo, Japan). The structural features of four catalysts were investigated by transmission electron microscopy (TEM) on a Philips CM20 (Eindhoven, Dutch) and FEI Tecnai F20 (Hillsboro, OR, USA).

Measurements of methanol synthesis activity were conducted in a fixed-bed stainless steel reactor. More details were included in our previous work [24]. One gram of catalyst was reduced in flowing dilute hydrogen $\left(5 \% \mathrm{H}_{2}\right.$ in $\left.\mathrm{Ar}\right)$ at $543 \mathrm{~K}$ for $2 \mathrm{~h}$. Then, methanol synthesis activity was measured at 40 bar and $260{ }^{\circ} \mathrm{C}$ with the GHSV $=3600 \mathrm{~h}^{-1}$. The reactant 
gas was composed of $25 \% \mathrm{CO}_{2}$ and $75 \% \mathrm{H}_{2}$. Concentrations of the product were analyzed using an online refinery gas analyzer (Clarus 580 GC; PerkinElmer, Waltham, MA, USA). Water was removed by cooling the product gas to $-1^{\circ} \mathrm{C}$. Then, analyses were conducted under isothermal conditions at $22{ }^{\circ} \mathrm{C}$. Product gas compositions were determined with reference to a series of calibration curves, which were constructed from the analysis of five standard gas mixtures.

\section{Results and Discussion}

\section{1. $\mathrm{N}_{2}$ Physisorption}

The $\mathrm{N}_{2}$ physisorption results for four catalysts are shown in Figure 1 . The catalyst of CZ-post presented a typical IV-type adsorption curve and H2 hysteresis loop. The adsorption curves of C-post and Z-post were type II and type I, respectively, and the hysteresis loops were type H4 and type H3 (without closure) [28]. These results indicated that both C-post and Z-post contained slit grooves formed by gathered particles (disclike or small cubes). The pore shape and size of C-post was more inerratic, while Z-post was irregular. CZ-in situ presented a typical IV-type adsorption curve and H1-type hysteresis loop, and the predominant adsorption finished between $\mathrm{P} / \mathrm{P} 0=0.6$ and 0.7 , which was a characteristic of the mesopores in the material. The results show that the samples loaded with $\mathrm{Cu}$ and $\mathrm{Zn}$ still had regular mesoporous channels.

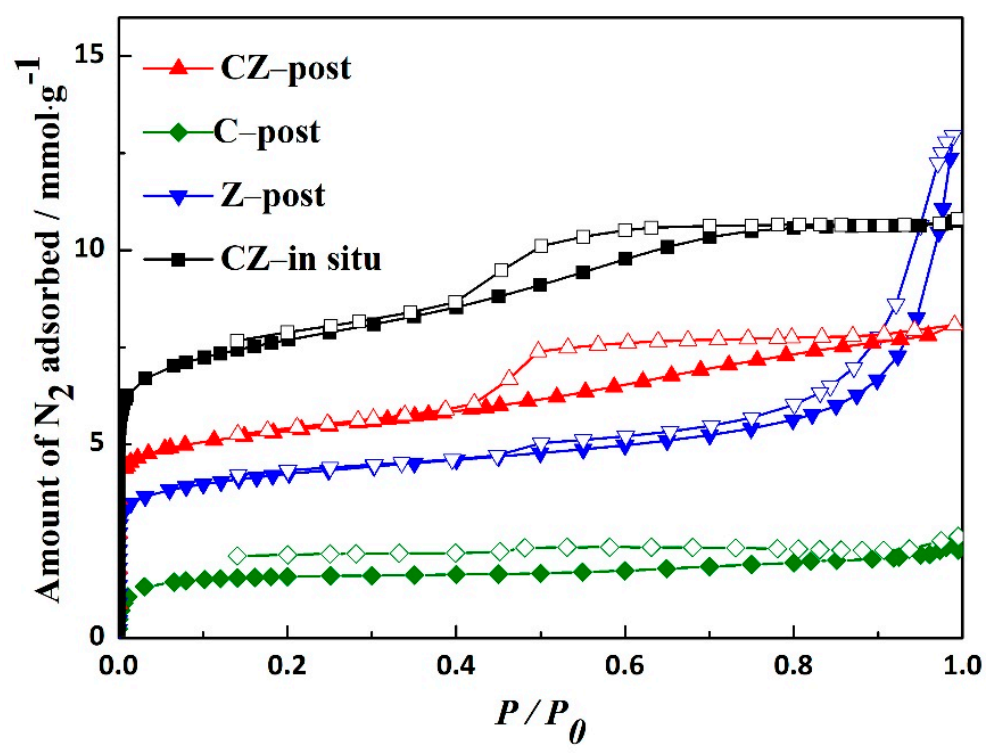

Figure 1. $\mathrm{N}_{2}$ adsorption and desorption isotherms of catalysts under $196^{\circ} \mathrm{C}$.

The pore size distribution of catalysts prepared by the precipitation method are shown in Figure 2. Micropores and mesoporous structures were discovered in the catalyst CZ-post. The highest frequency of micropores was $0.6 \mathrm{~nm}$. The mesoporous distribution range was from 2 to $9 \mathrm{~nm}$, and the highest occurrence frequency was $5 \mathrm{~nm}$. From the pore size distribution curves, it can be seen that the micropores of C-post and Z-post were gathered in the range of 1-2 nm, and there were almost no mesoporous pores. The highest microporous frequency of catalyst CZ-in situ appeared at $0.6 \mathrm{~nm}$, the mesoporous distribution was from 2 to $8 \mathrm{~nm}$, and the highest frequency was $6 \mathrm{~nm}$.

It can be concluded that the distribution of pore size was significantly affected by the calcination temperature and precursors, and a higher roasting temperature in a certain range and carbonization before adding the precursor would benefit pore structure development.

Table 1 summarizes the results for BET surface area, specific pore volume, micropore volume and mesoporous pore volume of the four catalysts. The BET surface area and pore volume of CZ-post were $416 \mathrm{~m}^{2} \cdot \mathrm{g}^{-1}$ and $0.28 \mathrm{~cm}^{3} \cdot \mathrm{g}^{-1}$, respectively. The pore volumes of micropores and mesopores were 0.18 and $0.09 \mathrm{~cm}^{3} \cdot \mathrm{g}^{-1}$, respectively. The BET surface area 
of C-post was $166 \mathrm{~m}^{2} \cdot \mathrm{g}^{-1}$. The pore volume was $0.11 \mathrm{~cm}^{3} \cdot \mathrm{g}^{-1}$. The micropore volume and mesoporous pore volume were 0.05 and $0.06 \mathrm{~cm}^{3} \cdot \mathrm{g}^{-1}$. The specific surface area of Z-post was $329 \mathrm{~m}^{2} \cdot \mathrm{g}^{-1}$, the pore volume was $0.45 \mathrm{~cm}^{3} \cdot \mathrm{g}^{-1}$ and the microporous volume was $0.09 \mathrm{~cm}^{3} \cdot \mathrm{g}^{-1}$. For catalysts C-post and Z-post, the total pore volume without micropore volume was the sum of the mesoporous and large-pore volume. The mesoporous volume could not be found in the PSD curve. Therefore, the large-pore volumes of two catalysts were 0.06 and $0.36 \mathrm{~cm}^{3} \cdot \mathrm{g}^{-1}$, respectively. The BET surface area of CZ-in situ was $596 \mathrm{~m}^{2} \cdot \mathrm{g}^{-1}$. The pore volume was $0.37 \mathrm{~cm}^{3} \cdot \mathrm{g}^{-1}$. The pore volume and mesoporous pore volume were 0.26 and $0.11 \mathrm{~m}^{3} \cdot \mathrm{g}^{-1}$, respectively.

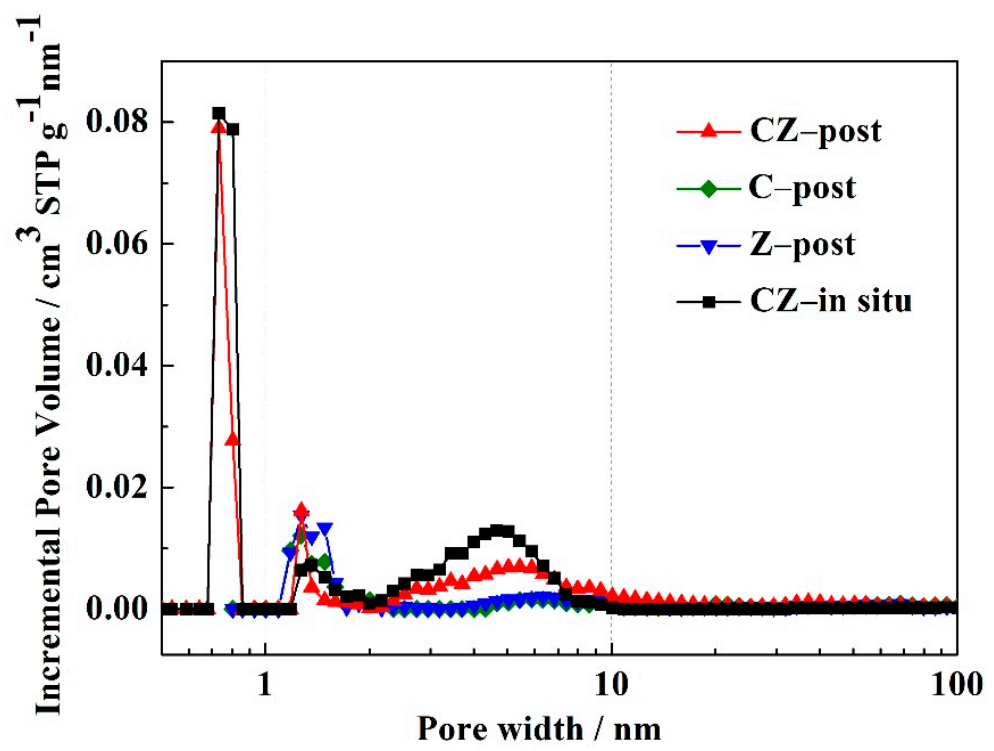

Figure 2. Pore size distribution curves of catalysts.

Table 1. Surface area and pore volumes of catalysts.

\begin{tabular}{|c|c|c|c|c|}
\hline Catalyst Name & $\begin{array}{l}\text { BET Surface Area } \\
\left(\mathrm{m}^{2} \cdot \mathrm{g}^{-1}\right)\end{array}$ & $\begin{array}{l}\text { Pore Volume } \\
\left(\mathrm{cm}^{3} \cdot \mathrm{g}^{-1}\right)\end{array}$ & Vmicro $\left(\mathrm{cm}^{3} \cdot \mathrm{g}^{-1}\right)$ & $\begin{array}{c}\text { Vmeso + Vmacro } \\
\left(\mathrm{cm}^{3} \cdot \mathrm{g}^{-1}\right)\end{array}$ \\
\hline CZ-post & 416 & 0.28 & 0.18 & 0.09 \\
\hline C-post & 166 & 0.11 & 0.05 & 0.06 \\
\hline Z-post & 329 & 0.45 & 0.09 & 0.36 \\
\hline CZ-in situ & 596 & 0.37 & 0.26 & 0.11 \\
\hline
\end{tabular}

It can be concluded that the surface area and pore volume were significantly affected by the precipitated precursor. The precipitated precursors of $\mathrm{Cu}$ and $\mathrm{Zn}$ were deposited on the carbon surface or carbon channel structure directly, which resulted in CZ-in situ with the highest BET surface. When the precursor of $\mathrm{Cu} \mathrm{Zn}$ precipitate was added and there was co-precipitation of $\mathrm{Cu}$ and $\mathrm{Zn}$ on the MC support, a higher BET surface area and regular channel structure could be generated in the catalyst. The BET specific surface area of the catalyst generated by adding only one of the precipitated precursors was small, and no mesoporous formation occurred.

\subsection{X-ray Diffraction}

Figure 3a shows the XRD patterns of different precipitated precursors. The XRD pattern of the $\mathrm{Zn}$ precipitate shows that the crystal of the precipitated precursor was $\mathrm{Zn}_{4} \mathrm{CO}_{3}(\mathrm{OH})_{6} \cdot \mathrm{H}_{2} \mathrm{O}$ (PDF No.11-287) and the crystal size was about $11 \mathrm{~nm}$ determined by Scherrer's equation. The XRD pattern of the $\mathrm{Cu}$ precipitate shows that the precursor was a mixture of $\mathrm{Cu}_{2}(\mathrm{OH})_{3} \mathrm{NO}_{3}$ (PDF No. 15-14) and $\mathrm{CuO}$ (PDF No. 80-76). The crystal size of $\mathrm{Cu}_{2}(\mathrm{OH})_{3} \mathrm{NO}_{3}$ was $68 \mathrm{~nm}$. The strength of $\mathrm{CuO}$ was too small to be calculated by Scherer's 
formula [29]. The XRD pattern of the $\mathrm{Cu} \mathrm{Zn}$ precipitate showed that the precursor was amorphous with a very broad peak packet $\left(2 \theta=30-40^{\circ}\right)$. Li [19] studied the influence of $\mathrm{pH}$ value and reaction temperature on the catalyst precursor. The results showed that it was conducive to generate $\mathrm{Cu}_{2}(\mathrm{OH})_{3} \mathrm{NO}_{3}$ when the $\mathrm{pH}$ value was less than 6 . The $\mathrm{PH}$ of the precipitate prepared in this manuscript is more than 7 , while it still generated $\mathrm{Cu}_{2}$ $(\mathrm{OH})_{3} \mathrm{NO}_{3}$. This is different to the literature.

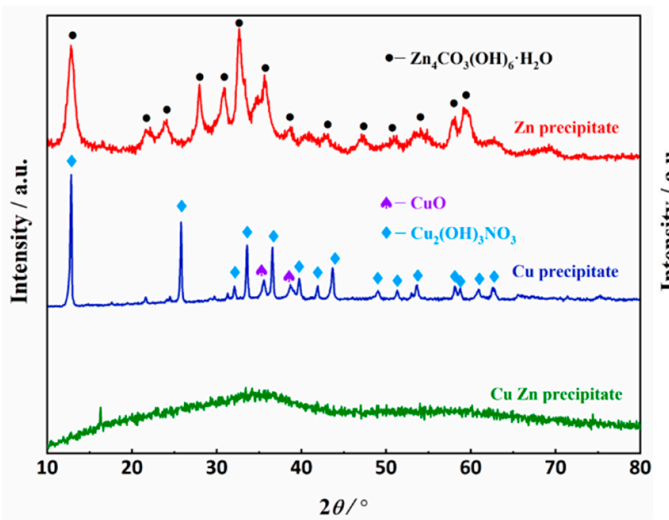

(a)

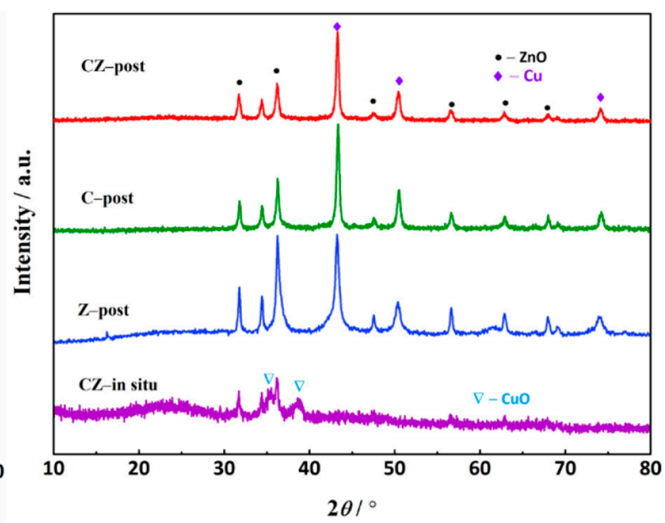

(b)

Figure 3. XRD spectra of (a) precipitated precursors; (b) four catalysts.

The XRD pattern of catalysts is shown in Figure 3b. It can be seen that the sharp diffraction peaks of $\mathrm{Cu}$ (PDF No.04-0836) and ZnO (PDF No. 89-0510) both appeared in the catalysts of CZ-post, C-post and Z-post. Those results show that both $\mathrm{Cu}$ and $\mathrm{ZnO}$ components in these catalysts were well crystallized. The $\mathrm{Cu}$ and $\mathrm{ZnO}$ crystal sizes of CZ-1 were about $14 \mathrm{~nm}$. For C-post, the $\mathrm{Cu}$ and $\mathrm{ZnO}$ crystal sizes were $18 \mathrm{~nm}$ and $20 \mathrm{~nm}$, respectively. For Z-post, they were about $27 \mathrm{~nm}$. For CZ-in situ, the XRD spectra had sharp $\mathrm{ZnO}$ peaks, and the crystal size of $\mathrm{ZnO}$ was about $11 \mathrm{~nm}$. The $\mathrm{CuO}$ spectra were very broad and had low intensity. The broadness of peak suggests that the crystal size of $\mathrm{CuO}$ (PDF No. 80-76) was very small.

From these results, it can be seen that the precipitated precursors of single precipitation were all well crystallized (CZ-post, C-post, and Z-post), and the co-precipitation products were amorphous (CZ-in situ). $\mathrm{Cu}$ and $\mathrm{ZnO}$ crystals appeared in the catalysts $\mathrm{CZ}$-post, $\mathrm{C}$-post, and Z-post. $\mathrm{ZnO}$ and $\mathrm{CuO}$ were observed in the catalyst $\mathrm{CZ}$-in situ. Besides, $\mathrm{CuO}$ was not reduced to $\mathrm{Cu}$ during roasting, and the crystal size of $\mathrm{CuO}$ was very small.

\subsection{TG-DTG Analysis}

The TG-DTG curves of different precipitated precursors and as-made FDU-15 with $\mathrm{Cu}$ Zn precipitate are shown in Figure $4 a-d$. According to Figure $4 a$, the total weight loss of the catalyst was $30 \%$, which could be divided into two parts. The first part was below $300{ }^{\circ} \mathrm{C}$ with slow weight loss, which might be the loss of interlamellar water and surface water of the catalyst. Another part appeared between 400 and $500{ }^{\circ} \mathrm{C}$, according to the analysis in the literature [30], which was the decomposition or release of $\mathrm{CO}_{2}$ and water. According to the TG-DTG result of $\mathrm{Cu}$ precipitation (Figure $4 \mathrm{~b}$ ), the total weight loss of precipitated precursor was $28 \%$, and it occurred from 150 to $250{ }^{\circ} \mathrm{C}$. Combined with the results of XRD (Figure 3a), the weight loss was a result of the decomposition and release of $\mathrm{H}_{2} \mathrm{O}$ and nitrides. For $\mathrm{Zn}$ precipitate (Figure 4c), its total weight loss was $34 \%$ with two stages. One stage appeared below $200^{\circ} \mathrm{C}$, which might be caused by the loss of interlamellar water and $\mathrm{OH}^{-}$in $\mathrm{Zn}_{4} \mathrm{CO}_{3}(\mathrm{OH})_{6} \cdot \mathrm{H}_{2} \mathrm{O}$ crystal [31]. The second stage appeared between $200{ }^{\circ} \mathrm{C}$ and $250{ }^{\circ} \mathrm{C}$, which came from the further decomposition of $\mathrm{OH}^{-}$and nitrous compounds. For as-made FDU-15 with $\mathrm{Cu} \mathrm{Zn}$ precipitate (Figure 4d), the total weight loss was $60 \%$ in two stages. Combined with the weight loss of as-made FDU 15 and precipitated precursors, in the first stage, the weight loss was due to the water loss of the precipitated precursor. 
The total weight loss was $10-15 \%$ within the range $230-250{ }^{\circ} \mathrm{C}$. Another weight loss was about $50 \%$ within the range $250-400{ }^{\circ} \mathrm{C}$. This was the common result of template F127 decomposition [27] and further decomposition of the precipitated precursor. It should be noted that the decomposition of as-made FDU-15 with $\mathrm{Cu} \mathrm{Zn}$ precipitate was not a simple addition of $\mathrm{Cu} \mathrm{Zn}$ precipitate and as-made FDU-15. Weightlessness appeared at a new location, which indicates that the mixing of these materials could decrease the decomposition temperature. The TG-DTG results were used to determine the calcination temperature of the catalysts. In order to ensure the full development of the pore structure of CZ-post, C-post and Z-post, the calcination temperature of these three catalysts was $700{ }^{\circ} \mathrm{C}$. Since CZ-in situ was supported on MC, MC was obtained by calcining as-made FDU 15 at $700{ }^{\circ} \mathrm{C}$. It should be noted that the full decomposition of the bulk $\mathrm{Cu} \mathrm{Zn}$ precipitate was at about $454{ }^{\circ} \mathrm{C}$. When supported on MC, the decomposition of the precursor could be reduced by forming small domains. Therefore, CZ-in situ was calcined at $300^{\circ} \mathrm{C}$ only for the decomposition of $\mathrm{Cu} \mathrm{Zn}$ precipitate.
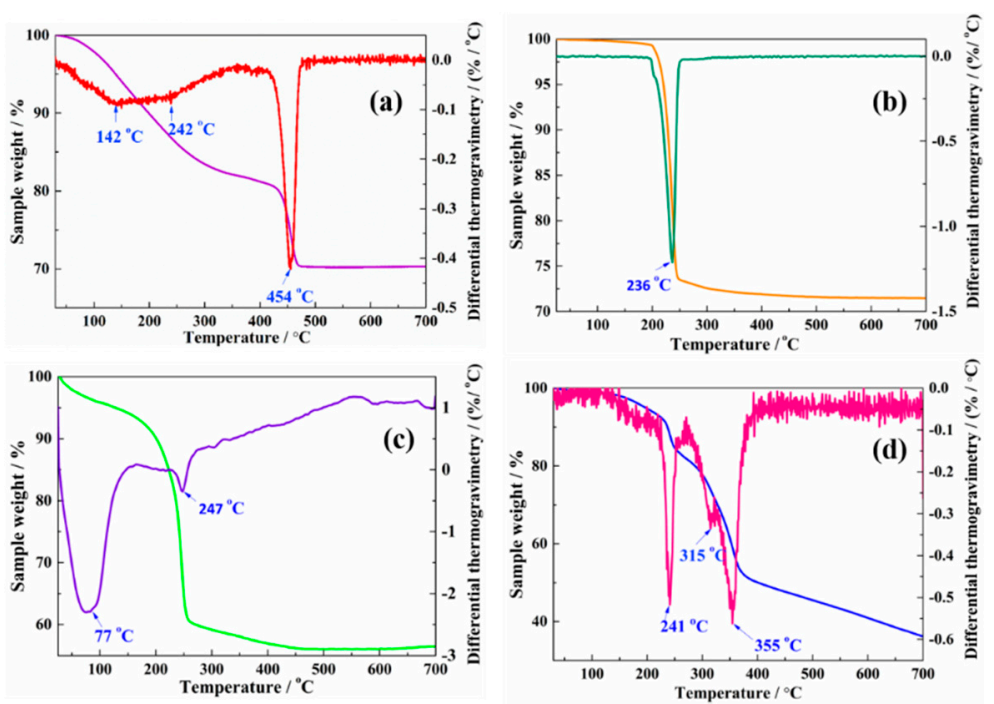

Figure 4. TG-DTG curves of precipitated precursors and as-made FDU-15 with $\mathrm{Cu} \mathrm{Zn}$ precipitate. (a) $\mathrm{Cu} \mathrm{Zn}$ precipitate; (b) $\mathrm{Cu}$ precipitate; (c) $\mathrm{Zn}$ precipitate; (d) as-made FDU-15 with $\mathrm{Cu}$ Zn precipitate.

\subsection{SEM and EDX}

\subsubsection{SEM}

Figure 5a-d show the SEM images of the catalysts. For CZ-post (Figure 5a), metals and metal oxides were wrapped in carbon support and dispersed evenly. For C-post (Figure 5b) and Z-post (Figure 5c), metal and metal oxides gathered on the surface of the support with a uniform particle size. Compared with four preparation methods of catalysts, it was easy to understand their distribution. For CZ-post, the precipitated precursor was dispersed in a FDU precursor solution to form membrane and carbonization. The precipitated precursor was wrapped by the carbon precursor during the membrane-making process. Therefore, the metal oxide after carbonization was also wrapped by the carbon support. For C-post and Z-post, they were different from crystal CZ-post. Both of them were added a precipitated precursor, while another precursor was dissolved in the carbon precursor. Therefore, some of the metals or metal oxides were deposited on the surface of the carbon support. In order to further understand the influence of precipitated precursor and nitrate precursor on the distribution of metal and metal oxides in the support, C-post and Z-post were performed by high-resolution SEM with EDX analysis, and the results and analysis are shown in Section 3.4.2. According to the XRD results (Figure 3), $\mathrm{Cu}$ and $\mathrm{ZnO}$ appeared in CZ-post, C-post and Z-post. Combined with the SEM results, $\mathrm{Cu}$ and $\mathrm{ZnO}$ in these catalysts had completely different distributions. For CZ-post, $\mathrm{Cu}$ and $\mathrm{Zn}$ nitrates were 
co-precipitated after addition of $\mathrm{Na}_{2} \mathrm{CO}_{3}$ and then added to the carbon precursor solution. The precipitation contained the mixed $\mathrm{Cu}$ and $\mathrm{Zn}$ hydroxides that decomposed into mixed $\mathrm{CuO}$ and $\mathrm{ZnO}$, which further reduced into $\mathrm{Cu} / \mathrm{ZnO}$ during the carbonization step [24]. Since these metals and metal oxides were formed during the carbonization step, they were hidden in the carbon matrix and had a limited area accessible to the reaction gas. However, because a precipitate was formed in the first step, this ensured the formation of $\mathrm{Cu}$ and $\mathrm{ZnO}$ in close proximity. For CZ-in situ, $\mathrm{Cu} \mathrm{Zn} \mathrm{precipitate} \mathrm{was} \mathrm{formed} \mathrm{after} \mathrm{the} \mathrm{carbon}$ formation, and it was distributed on the surface of the carbon supports.
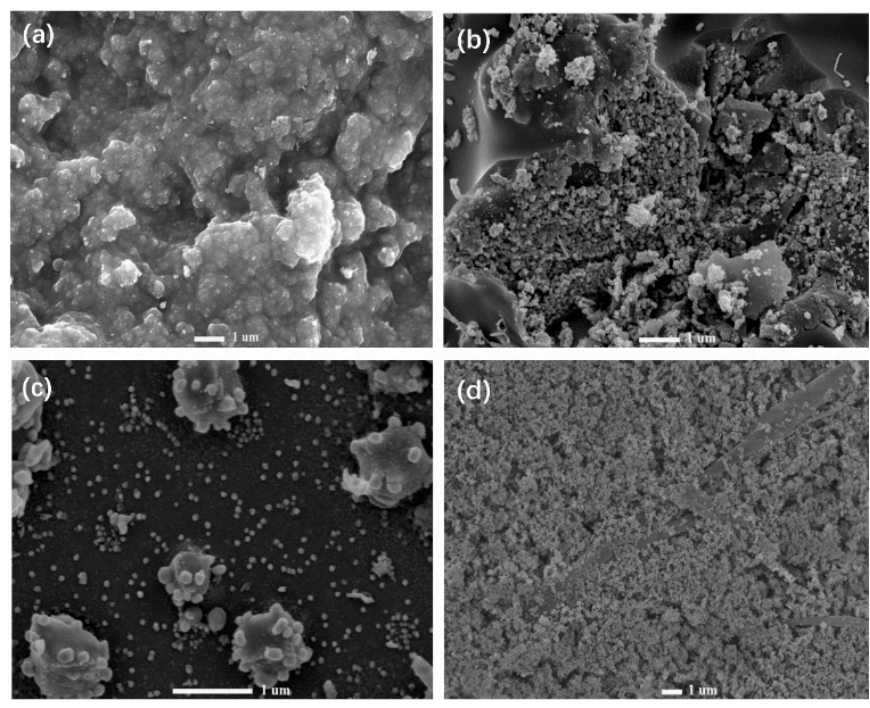

Figure 5. SEM images of catalysts: (a) CZ-post; (b) C-post; (c) Z-post; (d) CZ-in situ.

Combined with the XRD results, $\mathrm{CuO}$ appeared in $\mathrm{CZ}$-in situ instead of $\mathrm{Cu}$. This might be due to the surface contact between the precipitated precursor and carbon support not being as strong as the other catalysts, and the carbon support could not reduce $\mathrm{CuO}$. Maybe the carbon support could not reduce the $\mathrm{CuO}$ to $\mathrm{Cu}$ at the calcination temperature of $300{ }^{\circ} \mathrm{C}$.

\subsubsection{EDX Analysis}

Figure $6 a-d$ show the EDX mapping of C-post. Figure $6 \mathrm{~b}$ shows the element mapping of $\mathrm{Cu}$; there was less $\mathrm{Cu}$ on the catalyst surface, which was due to the $\mathrm{Cu}$ precipitate in the preparation process of the catalyst being wrapped by the carbon precursor. After calcination, only some $\mathrm{Cu}$ metal particles were exposed on the surface. According to the $\mathrm{O}$ and $\mathrm{Zn}$ element mapping (Figure $6 \mathrm{c}, \mathrm{d}$ ), this was due to the $\mathrm{ZnO}$ particles on the surface of $\mathrm{C}$-post. Figure $7 \mathrm{a}-\mathrm{d}$ show that the metal or metal oxide particles of $Z$-post catalyst were $\mathrm{Cu}$ and $\mathrm{ZnO}$. O elements almost occupied the entire surface of the catalyst, which could reveal that $\mathrm{O}$ had a corresponding high-brightness state where $\mathrm{Zn}$ appears, and when $\mathrm{Cu}$ appeared, the same high-brightness disappeared. Therefore, they were $\mathrm{Cu}^{0}$ and zinc oxide, which was consistent with the XRD results. In addition to the $\mathrm{O}$ element from $\mathrm{ZnO}$, the $\mathrm{O}$ element occupied the whole the carbon support. EDX spectra of the corresponding region of the catalyst $\mathrm{C}$-post showed that $\mathrm{Cu}$ content was $4.1 \%$ and $\mathrm{ZnO}$ content was 55.6\%. While Z-post was different from the catalyst C-post, the addition of Zn precipitation did not cause $\mathrm{ZnO}$ to be wrapped completely by the carbon support. A large amount of $\mathrm{ZnO}$ could be observed on the surface of the carbon support. According to the EDX results, the content of $\mathrm{Cu}$ was $52.7 \%$ and the $\mathrm{Zn}$ was $24.5 \%$, which was close to the theoretical molar ratio of $\mathrm{Cu}: \mathrm{ZnO}=2: 1$. Therefore, it could be that the addition of $\mathrm{Zn}$ precipitate and $\mathrm{Cu}\left(\mathrm{NO}_{3}\right)_{2} \cdot \mathrm{H}_{2} \mathrm{O}$ were conducive to the formation of evenly dispersed $\mathrm{Cu}$ and $\mathrm{ZnO}$. 

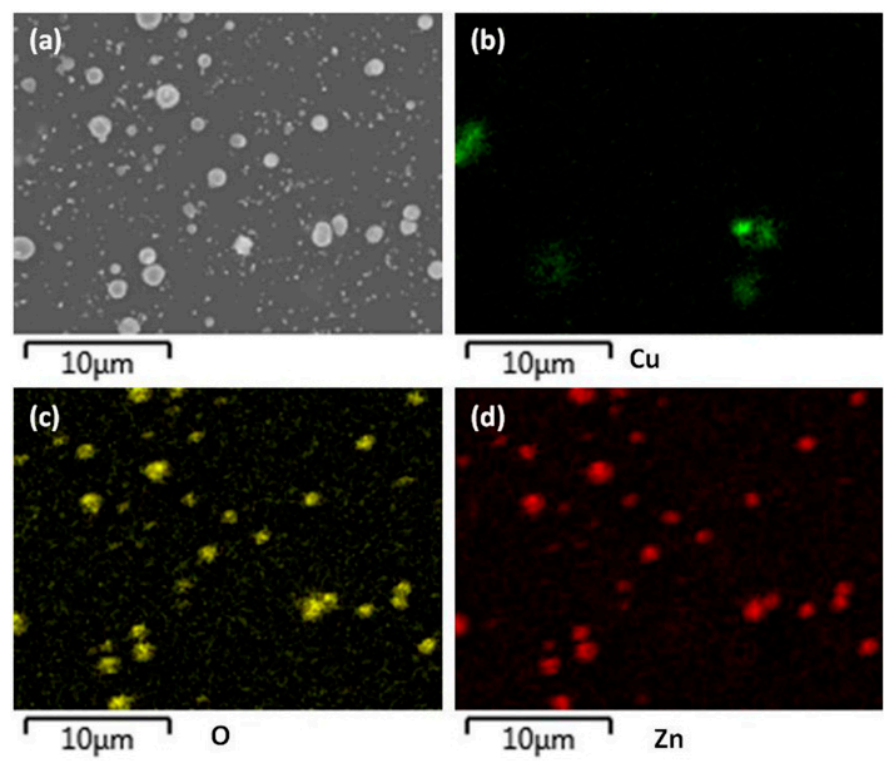

Figure 6. EDX mapping of catalyst C-post. (a) SEM image; (b) Cu element mapping; (c) O element mapping; (d) Zn element mapping.
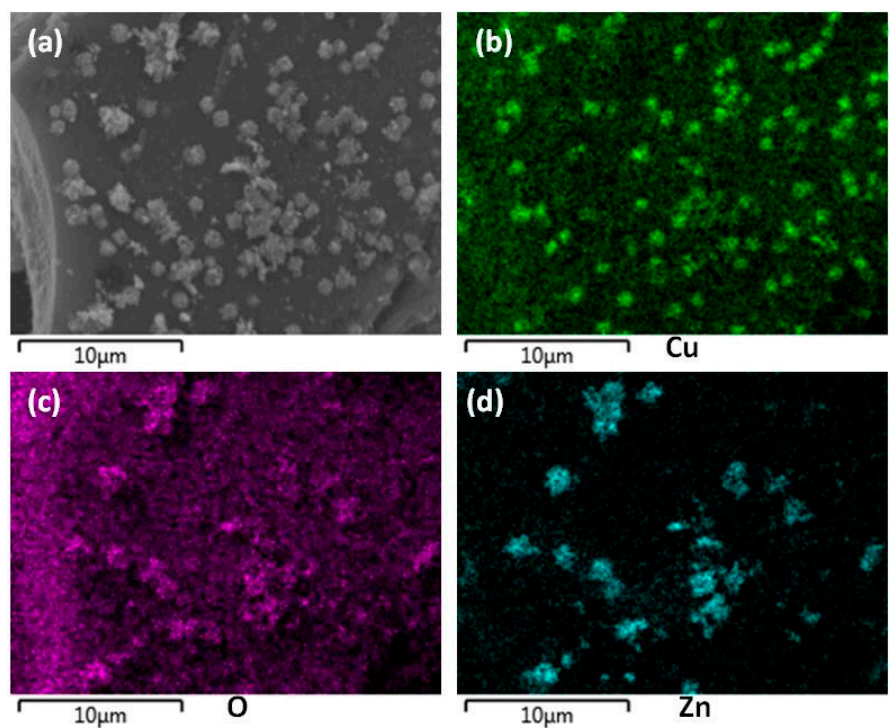

Figure 7. EDX mapping of catalyst Z-post. (a) SEM image; (b) Cu element mapping; (c) O element mapping; (d) Zn element mapping.

\subsection{TEM Analysis}

Figure $8 \mathrm{a}-\mathrm{d}$ show the TEM images of the four catalysts. Most of the metal or metal oxide loaded on the CZ-post dispersed evenly. In addition, some of them were aggregated (Figure 8a). The size of the metal oxides was 30-70 nm. From the TEM results (Figure 8b,c), the metal and metal oxide distribution of C-post and Z-post were similar. For C-post, the loaded metal was dispersed on the carbon support with uniform particle sizes of 20-40 $\mathrm{nm}$. Figure $8 \mathrm{c}$ shows that the nanoparticles of Z-post were distributed uniformly on the carbon matrix in the range $20-55 \mathrm{~nm}$. The average size was about $41 \mathrm{~nm}$. For catalyst CZ-in situ (Figure $8 \mathrm{~d}$ ), more than half of the particle sizes were $30-50 \mathrm{~nm}$, which were $\mathrm{Cu}$ and $\mathrm{Zn}$ clusters composed of metal oxide particles.

From these results, it can be seen that the distribution of metal and metal oxides in the catalysts obtained by different precipitated precursors was different, whether they were embodied by carbon support or not. 

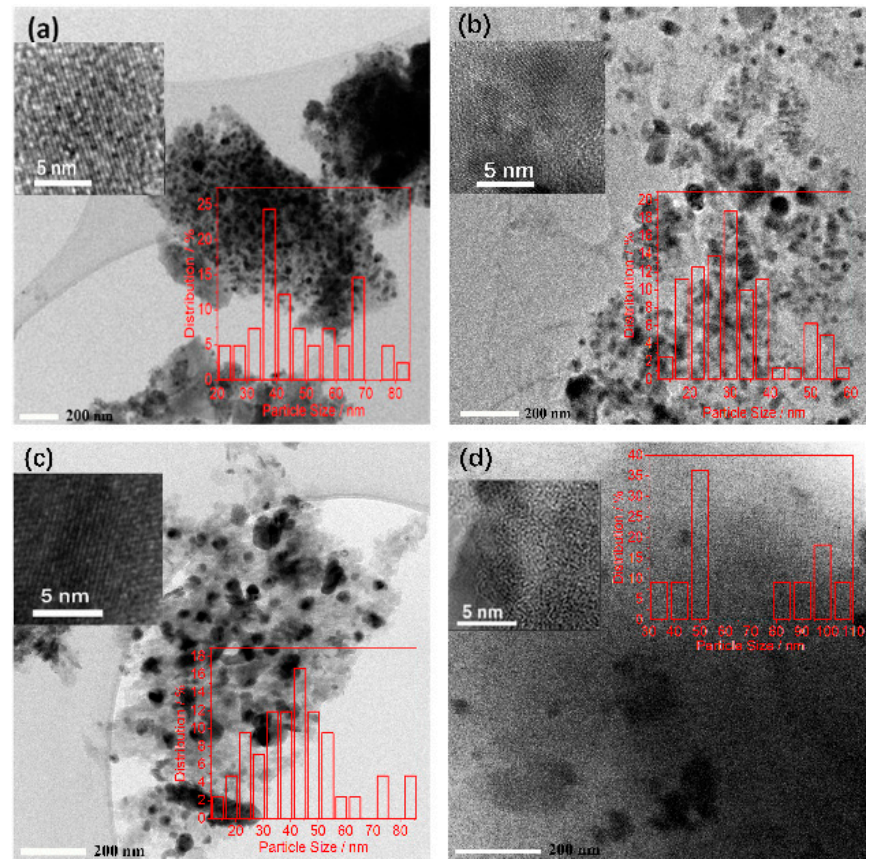

Figure 8. TEM images of catalysts. (a) CZ-post; (b) C-post; (c) Z-post; (d) CZ-in situ.

\subsection{Catalytic Performance Test}

3.6.1. Calculation of Methanol Formation Rate

Methanol formation rate is the mass-time yield per gram of catalyst, and the calculation method is shown in Equation (1).

$\mathrm{CH}_{3} \mathrm{OH}$ formation rate $\left(\mathrm{mmol} \cdot \mathrm{g}^{-1} \cdot \mathrm{h}^{-1}\right)=\frac{\left(\mathrm{CO}_{2} \text { conversion } \times \mathrm{CH}_{3} \mathrm{OH} \text { selectivity }\right) \times n_{\mathrm{CO}_{2}}^{\text {in }}}{22.4 \times 10^{3} \times m}$

where $m$ is the mass of the catalysts $(\mathrm{g})$.

\subsubsection{Calculation of $\mathrm{Cu}$ Surface Area}

$\mathrm{Cu}$ surface area was measured by $\mathrm{N}_{2} \mathrm{O}$ chemisorption on a Micromeritics Autochem HP 2950 apparatus [32,33]. The main equation involved is shown in Equation (2) [34]. Typically, $0.05 \mathrm{~g}$ catalyst was placed in a u-shaped tube. It was dried for $2 \mathrm{~h}$ at $120{ }^{\circ} \mathrm{C}$ under a He atmosphere, then heated up to $220^{\circ} \mathrm{C}$. It was reduced from $\mathrm{Cu}^{2+}$ to $\mathrm{Cu}^{0}$ at $270{ }^{\circ} \mathrm{C}$ for $2 \mathrm{~h}$ under a $\mathrm{H}_{2}$ atmosphere, and the temperature was reduced to $90{ }^{\circ} \mathrm{C}$ under a He atmosphere. Then, $\mathrm{N}_{2} \mathrm{O}$ was introduced to oxidize $\mathrm{Cu}^{0}$ to $\mathrm{Cu}^{+}$. Meanwhile, $\mathrm{N}_{2} \mathrm{O}$ was reduced to $\mathrm{N}_{2}$ [35]. TCD detected the $\mathrm{N}_{2}$ signal by comparing with the standard curve to determine the $\mathrm{Cu}$ surface area, and finally calculated the surface area of $\mathrm{Cu}$ by Equation (3).

$$
\begin{gathered}
2 \mathrm{Cu}+\mathrm{N}_{2} \mathrm{O}=\mathrm{Cu}-\mathrm{O}-\mathrm{Cu}+\mathrm{N}_{2} \\
\text { Cu surface area }\left(\mathrm{m}^{2} \cdot \mathrm{g}^{-1}\right)=\frac{n \times S F \times \mathrm{N} \times s}{m}
\end{gathered}
$$

where $n$ is the mole number of $\mathrm{N}_{2}$ formed in the reaction;

$S F$ is the stoichiometric coefficient, 2;

$\mathrm{N}$ is Avogadro's constant, $6.02 \times 10^{23}$;

$s$ is each $\mathrm{Cu}$ atom area, $0.068 \times 10^{-18}\left(\mathrm{~m}^{2}\right)$;

$m$ is the mass of the catalyst $(\mathrm{g})$. 


\subsubsection{Turnover Frequency (TOF)}

The turnover frequency (TOF) of per unit $\mathrm{Cu}$ area was used to compare the intrinsic catalytic activity of different catalysts, and the calculation method is shown in Equation (4).

$$
\operatorname{TOF}\left(\mathrm{s}^{-1}\right)=\frac{\mathrm{CH}_{3} \mathrm{OH} \text { formation rate } \times \mathrm{N} \times \mathrm{s}}{\text { Cu surface area } \times 3600}
$$

where $\mathrm{N}$ is Avogadro's constant, $6.02 \times 10^{23}$;

$s$ is each $\mathrm{Cu}$ atom area $\left(\mathrm{m}^{2}\right)$;

$\mathrm{Cu}$ surface area is Equation (3).

\subsection{Analysis of Catalytic Performance}

The metal loading amount, effective $\mathrm{Cu}$ surface area, $\mathrm{CO}_{2}$ conversion, methanol formation rate and TOF for catalysts are summarized in Table 2. The effective $\mathrm{Cu}$ surface areas of the four catalysts were in the range 0.5 to $3.3 \mathrm{~m}^{2} \cdot \mathrm{g}^{-1}$, which was $2.9 \mathrm{~m}^{2} \cdot \mathrm{g}^{-1}$ for CZ-post, $1.5 \mathrm{~m}^{2} \cdot \mathrm{g}^{-1}$ for C-post, $0.5 \mathrm{~m}^{2} \cdot \mathrm{g}^{-1}$ for Z-post and $3.3 \mathrm{~m}^{2} \cdot \mathrm{g}^{-1}$ for CZ-in situ. The metal loading amounts of CZ-post, C-post, Z-post and CZ-in situ were 15, 35, 41 and 10\%, respectively. $\mathrm{CO}_{2}$ conversions of these four catalysts were $5.3,3.5,2.5$ and $7.3 \%$, respectively. It was known that high metal loading on the catalyst was important for high methanol conversion. The metal loading amounts of C-post and Z-post were far higher than the other catalysts, but both of them had little activity. Methanol formation rate results indicate that the catalyst of CZ-in situ produced a methanol rate of $0.8 \mathrm{mmol} \cdot \mathrm{g}^{-1} \cdot \mathrm{h}^{-1}$. It is worth noting that the TOF of CZ-in situ was $2.8 \times 10^{-3} \mathrm{~s}^{-1}$ with the metal loading amount of $10 \%$. Because of the precursors, the catalytic performances were different. The catalyst state may be more complex than has been realized before.

Table 2. Metal loading amount, effective Cu surface area, methanol formation rate and TOF of the catalysts.

\begin{tabular}{|c|c|c|c|c|c|}
\hline Catalyst Name & $\begin{array}{c}\text { Metal Loading } \\
\text { Amount }^{\text {a }} \text { (wt.\%) }\end{array}$ & $\mathrm{Cu}-\mathrm{A}^{\mathrm{b}}\left(\mathrm{m}^{2} \cdot \mathrm{g}^{-1}\right)$ & $\begin{array}{c}\mathrm{CO}_{2} \text { Conversion } \\
(\%)\end{array}$ & $\begin{array}{c}\operatorname{MTY}^{\mathrm{c}} \\
\left(\mathrm{mmol} \cdot \mathrm{g}^{-1} \cdot \mathrm{h}^{-1}\right)\end{array}$ & TOF $^{d} \times 10^{3}\left(s^{-1}\right)$ \\
\hline CZ-post & 15 & 2.9 & 5.3 & 0.4 & 1.5 \\
\hline C-post & 35 & 1.5 & 3.5 & 0.05 & 0.4 \\
\hline Z-post & 41 & 0.5 & 2.5 & 0.04 & 0.9 \\
\hline CZ-in situ & 10 & 3.3 & 7.3 & 0.8 & 2.8 \\
\hline
\end{tabular}

${ }^{\mathbf{a}}$ Obtained from TGA tests in $\mathrm{O}_{2}$ atmosphere. ${ }^{\mathbf{b}}$ Effective $\mathrm{Cu}$ surface area. ${ }^{\mathbf{c}}$ Mass-time yield per gram of catalyst. ${ }^{\mathbf{d}}$ TOF was calculated from the methanol formation rate and the number of moles of the available $\mathrm{Cu}$ atoms determined from the effective $\mathrm{Cu}$ surface area.

For CZ-post, the $\mathrm{Cu}$ and $\mathrm{Zn}$ nitrates were precipitated and then added to the carbon precursor solution, and for catalyst $\mathrm{CZ}$-in situ, the $\mathrm{Cu}$ and $\mathrm{Zn}$ nitrates were co-precipitated directly on the carbon surface. Both of them showed a higher activity. However, C-post and Z-post had very low catalytic activity when only one of the precipitation products was added to another nitrate precursor. According to our previous work [24], the precipitation in the preparation process contains the mixed hydroxides of $\mathrm{Cu}$ and $\mathrm{Zn}$ that decompose into $\mathrm{Cu}$ and $\mathrm{Zn}$ oxide clusters, which are further reduced to $\mathrm{Cu} / \mathrm{ZnO}$ during the carbonization process. Since these $\mathrm{Cu} / \mathrm{ZnO}$ oxide clusters were formed simultaneously during the formation of the carbon support, they were generally hidden in the carbon support and could not fully access the reaction gas. However, due to the precipitate formed first (CZpost), this ensured the full contact between $\mathrm{Cu}$ and $\mathrm{ZnO}$, which could form the active center of electron transfer and activated the reaction gas, so that the reaction could proceed.

The precipitations of $\mathrm{Cu}$ and $\mathrm{Zn}$ were directly deposited on the carbon surface or carbon channel structure in CZ-in situ. Hence, more metal and metal oxides were accessible to the reaction gas. $\mathrm{Cu}$ and $\mathrm{Zn}$ metal oxide nanoparticles formed had higher activity when compared with CZ-post. In other words, for CZ-in situ, not only were the nanoparticles of $\mathrm{CuO}$ and $\mathrm{ZnO}$ in close proximity, but these metal oxide clusters could also make direct contact with the reaction gas. This was why the activity of CZ-in situ was the highest among 
the four catalysts. In addition, the dispersed $\mathrm{Cu} / \mathrm{ZnO}$ materials were rich in (oxidizable) defects in the $\mathrm{ZnO}$ surface, which was expected to be favorable for catalysis [36]. There was a good correlation between the activity of copper/zinc catalysts and copper metal surface area, so high activity in these catalysts is achieved by the preparation of a high dispersion of copper [37,38]. The homogeneous Cu-dispersion usually leads to an equally accessible $\mathrm{Cu}$ surface and methanol activities, but there were exceptions. Compared to C-post, Z-post had three times the $\mathrm{Cu}$ surface area, but these two catalysts showed similar activity per gram of catalyst. CZ-in situ had a slightly higher $\mathrm{Cu}$ surface area than CZ-post, but the catalytic activity was doubled. These two catalysts were much more active than C-post and Z-post. CZ-post and CZ-in situ had more Cu-ZnO interfaces compared to C-post and $\mathrm{Z}$-post. Therefore, we could conclude that other than high $\mathrm{Cu}$ surface area, the $\mathrm{Cu}-\mathrm{ZnO}$ interface was significant to the catalytic activity. A maximized $\mathrm{Cu}-\mathrm{ZnO}$ interface is crucial for methanol activities.

\section{Conclusions}

In summary, we demonstrated the synthesis of methanol catalysts with different precursors, i.e., $\mathrm{Cu}$ or/and $\mathrm{Zn}$ precipitated precursors. The addition of $\mathrm{Cu} \mathrm{Zn}$ precipitated precursor and co-precipitation on an $\mathrm{MC}$ support led to the formation of $\mathrm{Cu}$ or $\mathrm{CuO} / \mathrm{ZnO}$ clusters providing a synergistic effect site. This result was conductive to evenly distributed metal oxide in the catalyst system and showed some catalytic activity. In CZ-in situ, not only were the nanoparticles of $\mathrm{CuO}$ and $\mathrm{ZnO}$ in close proximity, but these metal oxide clusters could also make direct contact with the reaction gas. It was active for methanol formation with a rate of $0.8 \mathrm{mmol} \cdot \mathrm{g}^{-1} \cdot \mathrm{h}^{-1}$ and Cu surface area of $3.3 \mathrm{~m}^{2} \cdot \mathrm{g}^{-1}$. Its TOF value $\left(2.8 \times 10^{-3} \mathrm{~S}^{-1}\right)$ was highest but the number of active centers needs to be improved. All results indicate that a better contact between the $\mathrm{Cu} / \mathrm{CuO}$ and $\mathrm{ZnO}$ particles was the active center of the methanol formation. However, the number of active centers needs to be increased.

Author Contributions: Conceptualization; Y.L. and H.D.; methodology; H.D. and G.L.; software, C.W.; formal analysis, Y.F.; data curation, H.D. and Y.F.; writing-original draft preparation, G.L. and Y.L.; writing-review and editing; Y.L. and H.D. All authors have read and agreed to the published version of the manuscript.

Funding: This research was funded by the National Natural Science Foundation of China (project No. 52074051, 51704048), the Natural Science Foundation of Chongqing (No. cstc2020jcyj-msxmX0794) and the fundamental funds for the Central Universities (No. 2020CDJ-LHSs-010).

Institutional Review Board Statement: Not applicable.

Informed Consent Statement: Not applicable.

Acknowledgments: The authors would like to thank Analytical and Testing Center of Chongqing University for $\mathrm{N}_{2}$ Physisorption, XRD, TG-DTG, SEM, TEM analysis.

Conflicts of Interest: This manuscript is fully original and has not been published before. It is not under our consideration for publication anywhere else. The submission has been approved by all co-authors and the responsible authorities.

\section{References}

1. Arán-Ais, R.M.; Dunfeng, G.; Cuenya, R.B. Structure- and Electrolyte-Sensitivity in $\mathrm{CO}_{2}$ Electroreduction. Acc. Chem. Res. 2018, 51, 2906-2917. [CrossRef]

2. Schneider, S.H. The Greenhouse Effect: Science and Policy. Science 1989, 243, 771-781. [CrossRef]

3. Lin, S.; Diercks, C.S.; Zhang, Y.B.; Kornienko, N.; Nickolos, E.M.; Zhao, Y.; Paris, A.R.; Kim, D.; Yang, P.; Yaghi, O.M.; et al. Covalent organic frameworks comprising cobalt porphyrins for catalytic $\mathrm{CO}_{2}$ reduction in water. Science 2015, 349, 1208-1213. [CrossRef] [PubMed]

4. O'Neill, S. Global $\mathrm{CO}_{2}$ Emissions Level Off in 2019, with a Drop Predicted in 2020. Engineering 2020, 6, 958-959. [CrossRef] [PubMed]

5. Gao, S.; Lin, Y.; Jiao, X.; Sun, Y.; Luo, Q.; Zhang, W.; Li, D.; Yang, J.; Xie, Y. Partially oxidized atomic cobalt layers for carbon dioxide electroreduction to liquid fuel. Nat. Cell Biol. 2016, 529, 68-71. [CrossRef] [PubMed] 
6. Zhang, W.; Hu, Y.; Ma, L.; Zhu, G.; Wang, Y.; Xue, X.; Chen, R.; Yang, S.; Jin, Z. Progress and Perspective of Electrocatalytic CO 2 Reduction for Renewable Carbonaceous Fuels and Chemicals. Adv. Sci. 2018, 5, 1700275. [CrossRef] [PubMed]

7. Wang, Y.; Gao, W.; Li, K.; Zheng, Y.; Xie, Z.; Na, W.; Jingguang, G.C.; Wang, H. Strong Evidence of the Role of $\mathrm{H}_{2} \mathrm{O}$ in Affecting Methanol Selectivity from $\mathrm{CO}_{2}$ Hydrogenation over $\mathrm{Cu}-\mathrm{ZnO}-\mathrm{ZrO}_{2}$. Chem 2019, 6, 419-430. [CrossRef]

8. Din, I.U.; Shaharun, M.S.; Alotaibi, M.A.; Alharthi, A.I.; Naeem, A. Recent developments on heterogeneous catalytic $\mathrm{CO}_{2}$ reduction to methanol. J. $\mathrm{CO}_{2}$ Util. 2019, 34, 20-33. [CrossRef]

9. $\mathrm{Wu}, \mathrm{J}$. Controllable Preparation of Photo-/Electro-Catalytic Materials and Their Catalytic Performance for Carbon Dioxide Reduction. Ph.D. Thesis, University of Science and Technology of China, Hefei, China, 2020.

10. Kattel, S.; Ramírez, P.J.; Chen, J.G.; Rodriguez, J.A.; Liu, P. Active sites for $\mathrm{CO}_{2}$ hydrogenation to methanol on $\mathrm{Cu} / \mathrm{ZnO}$ catalysts. Science 2017, 355, 1296-1299. [CrossRef] [PubMed]

11. Li, C.; Yuan, X.; Fujimoto, K. Development of highly stable catalyst for methanol synthesis from carbon dioxide. Appl. Catal. A Gen. 2014, 469, 306-311. [CrossRef]

12. Ren, S.; Fan, X.; Shang, Z.; Shoemaker, W.R.; Ma, L.; Wu, T.; Li, S.; Klinghoffer, N.B.; Yu, M.; Liang, X. Enhanced catalytic performance of $\mathrm{Zr}$ modified $\mathrm{CuO} / \mathrm{ZnO} / \mathrm{Al}_{2} \mathrm{O}_{3}$ catalyst for methanol and DME synthesis via $\mathrm{CO}_{2}$ hydrogenation. J. CO $\mathrm{C}_{2}$ til. 2020, 36, 82-95. [CrossRef]

13. Ren, S.; Shoemaker, W.R.; Wang, X.; Shang, Z.; Klinghoffer, N.; Li, S.; Yu, M.; He, X.; White, T.A.; Ling, X. Highly active and selective $\mathrm{Cu}-\mathrm{ZnO}$ based catalyst for methanol and dimethyl ether synthesis via $\mathrm{CO}_{2}$ hydrogenation). Fuel 2019, 239, 1125-1133. [CrossRef]

14. Nitta, Y.; Fujimatsu, T.; Okamoto, Y.; Imanaka, T. Effect of starting salt on catalytic behaviour of $\mathrm{Cu}^{-\mathrm{ZrO}_{2}}$ catalysts in methanol synthesis from carbon dioxide. Catal. Lett. 1993, 17, 157-165. [CrossRef]

15. An, H.; Zhang, L.; Zhao, X.; Wang, Y. Effect of preparation conditions on the catalytic performance of $\mathrm{Cu}-\mathrm{Fe} / \mathrm{ZrO} 2 \mathrm{for}$ the synthesis of DPU from aniline and $\mathrm{CO}_{2}$. Chem. Eng. J. 2014, 255, 266-273. [CrossRef]

16. Costantino, U.; Marmottini, F.; Sisani, M.; Montanari, T.; Ramis, G.; Busca, G.; Turco, M.; Bagnasco, G. Cu-Zn-Al hydrotalcites as precursors of catalysts for the production of hydrogen from methanol. Solid State Ion. 2005, 176, 2917-2922. [CrossRef]

17. Li, J.-L.; Inui, T. Characterization of precursors of methanol synthesis catalysts, copper/zinc/aluminum oxides, precipitated at different pHs and temperatures. Appl. Catal. A Gen. 1996, 137, 105-117. [CrossRef]

18. Himelfarb, P.; Simmons, G.; Klier, K.; Herman, R. Precursors of the copper-zinc oxide methanol synthesis catalysts. J. Catal. 1985, 93, 442-450. [CrossRef]

19. Pollard, A.M.; Spencer, S.M.; Thomas, R.G.; Williams, P.A.; HolT, J.; Jennings, J.R. Georgeite and azurite as precursors in the preparation of co-precipitated copper/zinc oxide catalysts. Appl. Catal. A Gen 1992, 85, 1-11. [CrossRef]

20. Spencer, M. Precursors of copper/zinc oxide catalysts. Catal. Lett. 2000, 66, 255-257. [CrossRef]

21. Shi, L.; Yang, G.; Tao, K.; Yoneyama, Y.; Tan, Y.; Tsubaki, N. An Introduction of CO2Conversion by Dry Reforming with Methane and New Route of Low-Temperature Methanol Synthesis. Acc. Chem. Res. 2013, 46, 1838-1847. [CrossRef]

22. Van De Berg, M.W.E.; Polarz, S.; Tkachenko, O.P.; Kähler, K.; Muhler, M.; Grünert, W. Dynamical Changes in the Cu-ZnO Interaction Observed in a Model Methanol Synthesis Catalyst. Catal. Lett. 2009, 128, 49-56. [CrossRef]

23. Van De Berg, M.W.E.; Polarz, S.; Tkachenko, O.P.; Klementiev, K.V.; Bandyopadhyay, M.; Khodeir, L.; Gies, H.; Muhler, M.; Grunert, W. $\mathrm{Cu} / \mathrm{ZnO}$ aggregates in siliceous mesoporous matrices: Development of a new model methanol synthesis catalyst. J. Catal. 2006, 241, 446-455. [CrossRef]

24. Duan, H.; Yang, Y.; Singh, R.; Chiang, K.; Wang, S.; Xiao, P.; Patel, J.; Danaci, D.; Burke, N.; Zhai, Y.; et al. Mesoporous Carbonsupported $\mathrm{Cu} / \mathrm{ZnO}$ for Methanol Synthesis from Carbon Dioxide. Aust. J. Chem. 2014, 67, 907-914. [CrossRef]

25. Duan, H.; Yang, Y.; Patel, J.; Dumbre, D.; Bhargava, S.K.; Burke, N.; Zhai, Y.; Webley, P.A. A facile method to synthesis a mesoporous carbon supported methanol catalyst containing well dispersed $\mathrm{Cu} / \mathrm{ZnO}$. Mater. Res. Bull. 2014, 60, 232-237. [CrossRef]

26. Ouyang, C.; Wei, H.; Li, Q.; Li, Y.; Duan, H.; Liu, J. Synthesis and Characterization of Catalysts Cu-ZnO Supported on Mesoporous Carbon FDU-15. J. Chin. Chem. Soc. 2018, 65, 793-800. [CrossRef]

27. Meng, Y.; Gu, D.; Zhang, F.; Shi, Y.; Yang, H.; Li, Z.; Yu, C.; Tu, B.; Zhao, D. Ordered mesoporous polymers and homologous carbon frameworks: Amphiphilic surfactant templating and direct transformation. Angew. Chem. Int. Ed. 2005, 44, 7053-7059. [CrossRef]

28. Leofanti, G.; Padovan, M.; Tozzola, G.; Venturelli, B. Surface area and pore texture of catalysts. Catal. Today 1998, 41, 207-219. [CrossRef]

29. Zhang, L.; Lin, J.; Chen, Y. Studies of surface $\mathrm{NiO}$ species in $\mathrm{NiO} / \mathrm{SiO} 2$ catalysts using temperature-programmed reduction and X-ray diffraction. J. Chem. Soc. Faraday Trans. 1992, 88, 2075-2078. [CrossRef]

30. Behrens, M.; Girgsdies, F.; Trunschke, A.; Schlogl, R. Minerals as Model Compounds for Cu/ZnO Catalyst Precursors: Structural and Thermal Properties and IR Spectra of Mineral and Synthetic (Zincian) Malachite, Rosasite and Aurichalcite and a Catalyst Precursor Mixture. Eur. J. Inorg. Chem. 2009, 2009, 1347-1357. [CrossRef]

31. Małecka, B.; Gajerski, R.; Małecki, A.; Olszewski, P.; Wierzbicka, M. Mass spectral studies on the mechanism of thermal decomposition of $\mathrm{Zn}\left(\mathrm{NO}_{3}\right)_{2} \cdot \mathrm{nH}_{2} \mathrm{O}$. Thermochim. Acta 2003, 404, 125-132. [CrossRef]

32. Xia, S.; Yuan, Z.; Wang, L.; Chen, P.; Hou, Z. Hydrogenolysis of glycerol on bimetallic Pd-Cu/solid-base catalysts prepared via layered double hydroxides precursors. Appl. Catal. A Gen. 2011, 403, 173-182. [CrossRef]

33. Yuan, Z.; Wang, L.; Wang, J.; Xia, S.; Chen, P.; Hou, Z.; Zheng, X. Hydrogenolysis of glycerol over homogenously dispersed copper on solid base catalysts. Appl. Catal. B Environ. 2011, 101, 431-440. [CrossRef] 
34. Duan, H.; Yang, Y.; Patel, J.; Burke, N.; Zhai, Y.; Webley, P.A.; Chen, D.; Long, M. The effect of the modification methods on the catalytic performance of activated carbon supported CuO-ZnO catalysts. Carbon Lett. 2018, 25, 33-42.

35. Scholten, J.J.F.; Konvalinka, J.A. Reaction of nitrous oxide with copper surfaces. Application to the determination of free-copper surface areas. Trans. Faraday Soc. 1969, 65, 2465-2473. [CrossRef]

36. Zwiener, L.; Girgsdies, F.; Brennecke, D.; Teschner, D.; Machoke, A.G.; Schlögl, R.; Frei, E. Evolution of zincian malachite synthesis by low temperature co-precipitation and its catalytic impact on the methanol synthesis. Appl. Catal. B Environ. 2019, 249, 218-226. [CrossRef]

37. Ding, W.; Liu, Y.; Wang, F.; Zhou, S.; Chen, A.; Yang, Y.; Fang, W. Promoting effect of a Cu-Zn binary precursor on a ternary $\mathrm{Cu}-\mathrm{Zn}-\mathrm{Al}$ catalyst for methanol synthesis from synthesis gas. RSC Adv. 2014, 4, 30677-30682. [CrossRef]

38. Kühl, S.; Friedrich, M.; Armbrüster, M.; Behrens, M. Cu, Zn, Al layered double hydroxides as precursors for copper catalysts in methanol steam reforming-pH-controlled synthesis by microemulsion technique. J. Mater. Chem. 2012, 22, 9632-9638. [CrossRef] 